\title{
DR. LENTNER CSABA (SZERK.): PÉNZPIACOK SZABÁLYOZÁSA MAGYARORSZÁGON
}

\author{
(Akadémiai Kiadó, Budapest, 2006, 327 o. \\ Lektorálta: Prof. Dr. Huszti Ernö DSc. c. egyetemi tanár)
}

\section{CSERMÁK KÁROLY}

Újabb könyv jelent meg a közelmúltban az Akadémiai Kiadó gondozásában a fenti címmel, amelyet mint szerkesztő, Dr. habil. Lentner Csaba neve fémjelez. A Nyugat-Magyarországi Egyetem Pénzügytan-Számvitel Intézetének igazgatója, számos hazai és külföldi tudományos szakfolyóiratban publikált figyelemfelkeltő cikk, tanulmány és több sikeres könyv szerzỏje, társszerzỏje most arra vállalkozott, hogy elismert pénzügyi szakemberek bevonásával egy olyan szakkönyvet tegyen le a gazdasági élet szereplöinek asztalára, amely a pénzpiaci, a jegybanki, a pénzmosás elleni szabályozással, a bank-és biztositási feliigyelet müködésével, valamint a tözsdei bevezetéssel és az állampapir-piacokkal foglalkozik. A pénzügyi szektor teljes körének szabályozási elemeivel foglalkozó könyv tartalma megszívlelendö mind a befektetők, mind a gazdasági fejlődés céljait szolgáló makrogazdasági és regionális területeken dolgozó szakemberek számára, hiszen a gazdasági, üzleti tevékenység sikeres viteléhez olyan információkat tartalmaz, amelyek a feltörekvő piacgazdaságból a fejlett piacgazdaságba araszolgató magyar gazdasági életben mára már elengedhetetlenek.

A könyv nyolc - a súlyuknak és jelentőségüknek megfelelö terjedelmü és részletezettségú - fejezetre tagolódik, melyek hasznos mellékletekkel, jogszabályi hivatkozásokkal és szakirodalom jegyzékkel egészülnek ki, lehetővé téve az olvasók további információs igényének kielégítését.

A szerkesztő a könyv előszavában lényegét és tartalmát tekintve is az ezredforduló utáni évek aktuális pénzpiaci szabályozásairól szól, amely napjainkra már szervesen illeszkedik az EU szabályozási rendszeréhez.

A neves kiadónál publikált könyv megjelenését az adott szakterületről úgynevezett „megalapozó” egyeterni jegyzetek, kiadványok előzték meg. Így a 2000-ben megjelent „Bankszabályozás az Európai Unióban” címü egyetemi jegyzet, Lentner Csaba és Tarpataki János szerzőpáros tollából, továbbá a 2002-ben napvilágot látott, ugyancsak egy többszerzős mü, „Bankszabályozás” címmel, amelynek megírásában már közremüködött Huszti Ernő professzor és Seregdi László PSZÁF főosztályvezető is. A pénzügyi szabályozás nyomon követése, a fejlödési tendenciák elemzése, a naprakész szakismeretek biztosítása, tulajdonképpen ezek azok a tényezök, amelyek Lentner Csabát arra sarkallták, hogy a korábbi egyetemi jegyzeteiket aktualizálja, korszerủ ismeretanyaggal bővítse Magyarország EU csatlakozásának második évében. A szakmai alapossággal és tudományos igénnyel összeállított 
fejezetek megírására megfelelő elméleti felkészültségü és egyúttal gyakorlati jártassággal rendelkezö szakembereket kért fel a könyv szerkesztöje. Így került a könyv társszerzőinek sorába Horváth Andrea, az AEGON Magyarország Általános Biztosító Rt. vezérigazgató-helyettese, Horváth Zsolt, a Budapesti Érték Tözsde (BÉT) vezérigazgatója, Forgács Péter, a Magyar Állam Kincstár (MÁK) föosztályvezetője és a Pénzügyi Szervezetek Állami Felügyeletének (PSZÁF) ügyvezető igazgatóhelyettese, Seregdi László.

A könyv egyes fejezeteinek megírásakor, egységes keretbe foglalásakor, még nyilván nem tornyosultak olyan vészjósló felhők a magyar gazdaság egén, mint ami napjainkban tapasztalható. Még mindig reális célként fogalmazódhatott meg 2006 év elején szinte az összes maastrichti kritérium teljesítése. Az infláció három százalék körüli mértéke, illetőleg az ezen a szinten történő megtartása biztosíthatónak tủnt. A magyar államadósság mértéke ekkor még mindig kisebb volt, mint a GDP 60\%-a, azonban növekedésével már számolni lehetett. A költségvetési hiány lefaragására is érthetö és hihető intézkedések sikerében lehetett bízni olyannyira, hogy az euró bevezetésének 2010-es végsö céldátuma egyáltalán nem tủnt elérhetetlennek. Azonban mára már - az ismert okokból - szertefoszlott ez az álom, és egy sor olyan bizonytalansági faktor torzítja a makrogazdasági mutatókat, amelyekre hosszú évek (évtizedek) óta nem volt példa. Persze könnyű ex postfacto kijelentéseket tenni a mában a tegnap posztulátumaival kapcsolatban. A mú érdeme tehát nem az, hogy mennyiben tudja megjósolni, hogy miképpen alakulhatnak a hazai makrogazdasági mutatók vagy, hogy mennyire tudja érvényesíteni az MNB monetáris politikájának legföbb célkitűzését, az árstabilitás elérését és fenntartását, hanem annak a szabályozói környezetnek a részletezése (jogszabályok, intézményi háttér, ellenörzési feladatok stb.), amely keretet szab(hat) a pénzpiacok szabályszerủ müködésének, ellenörizhetővé teszi a pénzügyi szervezetek müködését és átláthatóbbá válnak a rendkívül szövevényes pénzügyi világ ismert és ismeretlen labirintusai.

A BÉT kiemelkedö fontossággal bír a pénzügyi intézményrendszerben. A BUX index látványos szárnyalása valóban azt igazolja vissza, hogy a befektetők optimisták, bíznak az ország, a meghatározó multinacionális cégek hazai töretlen és fokozódó többletteljesítésében, a szilárd gazdaságpolitikai elvek megvalósításában, a már itt lévő töke megtartásában és a további magyarországi befektetésekben.

Az 1987. január 1. óta múködő kétszintü bankrendszer mára „felnötté” vált. Bizonyítják ezt a kereskedelmi bankszektor jövedelmezőségi mutatóinak imponáló számai, amelyek évröl-évre növekedést mutatnak. A kereskedelmi banki tevékenységek „,nemzetköziesedését" jelzi az a tény is, hogy tovább növekszik a háztartásoknak nyújtott hitelállomány és annak devizaaránya is. Bár ezzel kapcsolatban meg kell jegyezni, hogy az annyira favorizált devizahitelek (CHF, EUR) HUF árfolyamkockázati negatív hatásai a hiteladósok nagy részét többlet kiadásokba sodorják. A jelenlegi hazai, bizonytalannak látszó gazdasági és politikai helyzet hektikusan mozgat(hat)ja a HUF árfolyamát. Az MNB alapkamat politikája próbálja ezt (is) ellensúlyozni. Óvatos lépésekben 25-50 bázispontokkal tornázta fel mára a jegybanki alapkamat szintjét $8 \%$-ra! 
A biztosítási szektor is stabil és megfelelỏen szabályozott a piacon. Díjbevétele gyakorlatilag arányosan változik a bruttó hazai termékkel, annak mintegy három százalékának felel meg, és „2000 óta több mint 50 százalékkal nött.”

A pénzügyi szektor minden terulleten ,felértékelödött". Ezt példázzák a könyv részletezö, a pénzügyi intézményrendszer müködését kellö alapossággal bemutató egyes fejezetei. Azon túlmenően, hogy betekintést adnak és teljességgel lefedik az egész pénzügyi rendszert (jegybank, hitelintézetek és pénzügyi szolgáltatást végzö egyéb szervezetek, tỏzsde, biztosítási piac, PSZÁF, MÁK, Államadósság Kezelö Központ Rt.), egyszersmind megkönnyítik „, a befektetök és a külsö finanszírozási forrást igénybevevók döntési pozícióit" is, hiszen a könyv ismeretanyagának felhasználásával akár a múködő-tőke, akár a pénzpiaci befektetök döntési pozíciói nagyobb körültekintéssel, illetve szakmai alapossággal végezhetöek.

Az értékes és sokrétü információt tartalmazó, közös szellemi alkotás elsősorban gyakorló közgazdászok és jogászok részére íródott, kézikönyv jelleggel, azonban igen hasznos ajánlott irodalom lehet a felsőfokú tanulmányaikat folytató közgazdász és jogász hallgatóknak is.

Külön érdeme és értéke ennek a kiadványnak, hogy a szerzők rövid nacionáléját is közli, közelebb hozván ezzel is a könyv Tisztelt Olvasóit és Íróit.

Remélhetöleg még sok hasonlóan érdekes és hasznos müvet fogunk megismerni Lentner Csabától, illetve a köré szervezödött tudományos mühely jóvoltából, akár a hazai, akár a külföldi könyvkiadók gondozásában. 
Tér és Társadalom 20. évf. 2006/3. 109-158. p. 